\title{
CLONING AND CHARACTERIZATION OF cobA, ONE OF VITAMIN B12 BIOSYNTHESIS PATHWAY GENES FROM Selenomonas ruminantium
}

\author{
LÍVIA FECSKEOVÁ, PETER PRISTAŠ, PETER JAVORSKÝ \\ Institute of Animal Physiology, Slovak Academy of Sciences, Šoltésovej 4-6, Košice, \\ Slovak Republic (fecskeova@saske.sk)
}

\begin{abstract}
Bacterial biosynthesis of vitamin $\mathrm{B}_{12}$ can occur via either aerobic or anaerobic route. While the aerobic pathway has been fully elucidated and understood, less is known about the anaerobic pathway. Selenomonas ruminantium is thought to be the main producer of this vitamin in rumen environment and must use the anaerobic pathway. In our work we found one of the genes of vitamin $\mathrm{B}_{12}$ biosynthetic pathway of S. ruminantium, encoding for the cobalamin adenosyltransferase, enzyme taking part at the last steps of the synthesis process. Deduced amino acid sequence showed the highest similarity to cobalamin adenosyltransferases of other ruminal anaerobic bacteria and that of species Selenomonas. Phylogenetic comparisons of CobA protein sequences of several anaerobic bacteria of Clostridiale order indicate possible horizontal transfer of this gene.
\end{abstract}

Key words: vitamin $\mathrm{B}_{12}$, cobalamin biosynthesis, Selenomonas ruminantium

\section{Introduction}

One of nature's structurally most complex small molecule, vitamin $\mathrm{B}_{12}$ or cobalamin, is an essential nutrient for humans and animals. It is used to treat pernicious anaemia and peripheral neuritis, and is used as a dietary supplement. While it is required in both prokaryotic and eukaryotic metabolism, only some bacterial and archaeal species are able to synthesize it de novo (RODIONOV et al., 2003). Some prominent $\mathrm{B}_{12}$-dependent reactions in bacteria and archaea include the process of acetate formation in acetogenic bacteria, transfer of methyl group in methaneproducing archaea and anaerobic fermentation of 1,2-propanediol, ethanolamine and glycerol in enteric bacteria (MARTEN et al., 2002). Animals and humans require $\mathrm{B}_{12}$ as coenzyme for two enzymes only: methionine synthase for homocysteine methylation and methylmalonyl-CoA mutase involved in oxidation of fatty acids and amino acids, respectively. Plants and fungi are thought to neither synthesize, nor need it (DUDA et al., 1967). Two different cobalamin synthetic pathways have been found - an evolutionally older anaerobic pathway found in Salmonella enterica or Propionibacterium shermanii (ROESSNER and SCOTT, 2006) and a more recent aerobic route in Pseudomonas denitrificans (BATTERSBY, 1994), which differ at the point of cobalt insertion. As the industrial production by chemical synthesis would be too expensive and technically demanding, vitamin $\mathrm{B}_{12}$ is produced industrially by biosynthetic fermentation processes, employing almost exclusively $P$. denitrificans and Propionibacterium species (MARTENS et al., 2002).

Selenomonas ruminantium, a gram-positive obligate anaerobe originally isolated from rumen of cattle, is one of the most numerous bacteria of the ruminal microbial 
population. Considerable metabolic role it plays in rumen is given by its capability to convert succinate to propionate and to utilize lactate and many amino acids (RICKE et al., 1996). Previous research has showed that this bacterium is the main $\mathrm{B}_{12}$ contributor to the rumen environment (DRYDEN et al., 1962), where its role is in the assimilation of propionic acid, a major fermentation product of the ruminal microflora, by $\mathrm{B}_{12}$-dependent methylmalonyl-CoA mutase.

\section{Materials and methods}

\subsection{Bacterial strain and growth conditions}

Bacterial strain S. ruminantium S8 was cultivated anaerobically in the atmosphere of pure $\mathrm{CO}_{2}$ in selective M10 broth medium (CALDWELL and BRYANT, 1966) with an addition of $10 \%$ clarified rumen fluid, $0.1 \%$ mineral solution and $0.1 \%$ vitamin solution (CLARK and HOLMS, 1976). Fructose (4g/L) was used as the sole carbon source.

\subsection{DNA isolation and PCR reaction}

Total DNA from bacterial cells was isolated by sodium dodecylsulphate lysis and subsequent phenol extractions (POSPIECH and NEUMANN, 1995). Total DNA was amplified in Techne TC 3000 (USA) thermal cycler in $50 \mu \mathrm{L}$ reaction mix containing $40 \mu \mathrm{mol} / \mathrm{L}$ each dNTP, $20 \mathrm{pmol}$ of each primer, $1 \mathrm{x}$ reaction buffer and $0.5 \mathrm{U}$ of Taq DNA polymerase (Invitrogen, Netherland). PCR primers used were SRDrecF (5'TCTCGAAAATGGGGCGCAGC3') and SRDrecR (5'TTTGAGAMACTCATAA GTGCGCATTC3'). Initial denaturation step $\left(95^{\circ} \mathrm{C} 5 \mathrm{~min}\right.$ ) was followed by 35 cycles $\left(94{ }^{\circ} \mathrm{C} 1 \mathrm{~min}, 58^{\circ} \mathrm{C} 1 \mathrm{~min}, 72{ }^{\circ} \mathrm{C} 1 \mathrm{~min}\right.$ ) and a final incubation at $72{ }^{\circ} \mathrm{C}$ for $10 \mathrm{~min}$.

\subsection{Molecular cloning and sequence analysis}

PCR amplicon was ligated into plasmid pTZ57R/T (Fermentas, Lithuania) and Escherichia coli ER2267 competent cells were transformed with the ligation mixture. Recombinant plasmid was extracted using the GeneJET Plasmid Miniprep kit (Fermentas, Lithuania) and the DNA insert was sequenced. Using the BLAST algorithm (ALTSCHUL et al., 1990) at NCBI the obtained nucleotide sequence was subjected to homology search against nucleotide and protein database. For phylogenetic comparisons MEGA 4 software (TAMURA et al., 2007) was used.

\section{Results and discussion}

Small plasmids of S. ruminantium were suggested to undergo recombination events during the rolling circle replication, when highly recombinogenic single-stranded plasmid intermediates form. Recombination is proposed to rely on highly conserved, short DNA sequences characteristic for many small RCR plasmids of S. ruminantium, 
such as the SRSR elements (Selenomonas Ruminantium Sequence Repeats) (NAKAMURA et al., 1999). During experiments on the possible role of SRSR mediated recombination in the plasmid evolution and spreading in S. ruminantium using PCR and specifically designed primers amplifying interchangeable plasmid rep cassettes multiple amplicons were obtained. While most of the obtained amplicons contained plasmid derived sequences encoding for replication protein (not published yet), surprisingly in one case the complete cobA gene encoding for cobalamin adenosyltransferase was present.

After PCR reaction we obtained an approximately $800 \mathrm{bp}$ amplicon, which we cloned and sequenced. While no significant similarity was observed at nucleotide level, the 780 bp DNA fragment contained single ORF encoding for a 178 amino acid protein with significant similarity to cob(I)alamine adenosyltransferase or cob(I)yrinic acid a,c-diamide adenosyltransferase, one of many enzymes of the $\mathrm{B}_{12}$ biosynthetic pathway. The sequence was submitted to GenBank database under the Accession Number HQ383925.

Comparison of the deduced amino acid sequence with the generalized structure of conserved domains of cobalamin adenosyltransferases (Fig. 1) shows the presence of all conserved domains, within which each amino acid is conserved according to the generalized structure. We found the presence of two Walker motifs type A and B, hydroxycobalamin binding site, ATP binding site and homodimer interface.

Derived protein sequence showed the highest similarity to Mitsuokella multiacida (65\% identity, $78 \%$ similarity), Megamonas hypermegale ART12/1 (64\% identity, $79 \%$ similarity), and S. flueggei ATCC 43531 (62\% identity, $79 \%$ similarity) CobA sequences.

Phylogenetic comparison of several available cobA genes of anaerobic bacteria (Fig. 2) within the Clostridiales order showed that S. ruminantium CobA sequence groups together with other Selenomonas spp. and related sequences. Surprisingly this group of CobA sequences is more related to the CobA sequences of Peptococcaceae family than to other members of Veillonellaceae family, where $S$. ruminantium belongs to, indicating possible horizontal gene transfer of cobA gene.

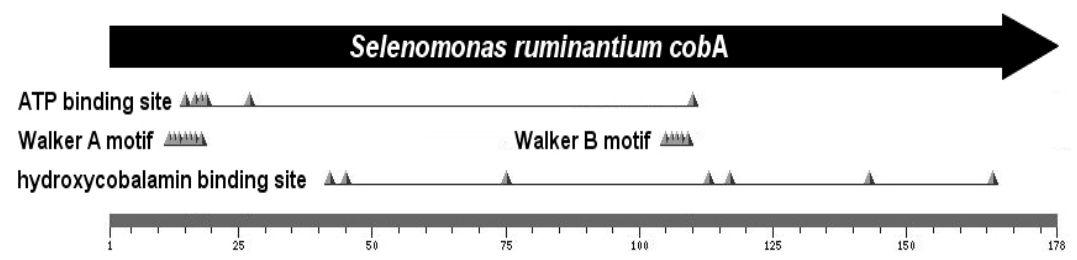

Fig. 1. Schematic representation of selected motifs in S. ruminantium cobA gene. The position of conserved amino acids characteristic for CobA protein domains is indicated by blafl triangles.

Importance of bacterial production of vitamin $\mathrm{B}_{12}$ is given by its role in the elimination of some volatile fatty acids produced in the rumen. Despite it very limited information is available on the genetic background of its production by ruminal selenomonads, which are the predominant suppliers of this vitamin to the rumen 
environment. So far, only one study has been performed investigating the $\mathrm{B}_{12}$ synthesis in S. ruminantium (ANDERSON et al., 2001), in which the authors described five genes organized as an operon, encoding for enzymes acting in the first steps of $\mathrm{B}_{12}$ synthesis. A bifunctional gene, $\operatorname{cob} A+$ hemD, coding for a protein with two catalylic functions - uroporphyrinogen III synthase and uroporphyrinogen III 2,7methyltransferase - was found and protein phylogenetic comparisons showed that this form of the enzyme is probably restricted to strictly anaerobic bacteria. The gene we describe here encodes for cobalamine adenosyltransferase, enzyme catalyzing one of the last steps of $\mathrm{B}_{12}$ biosynthesis.

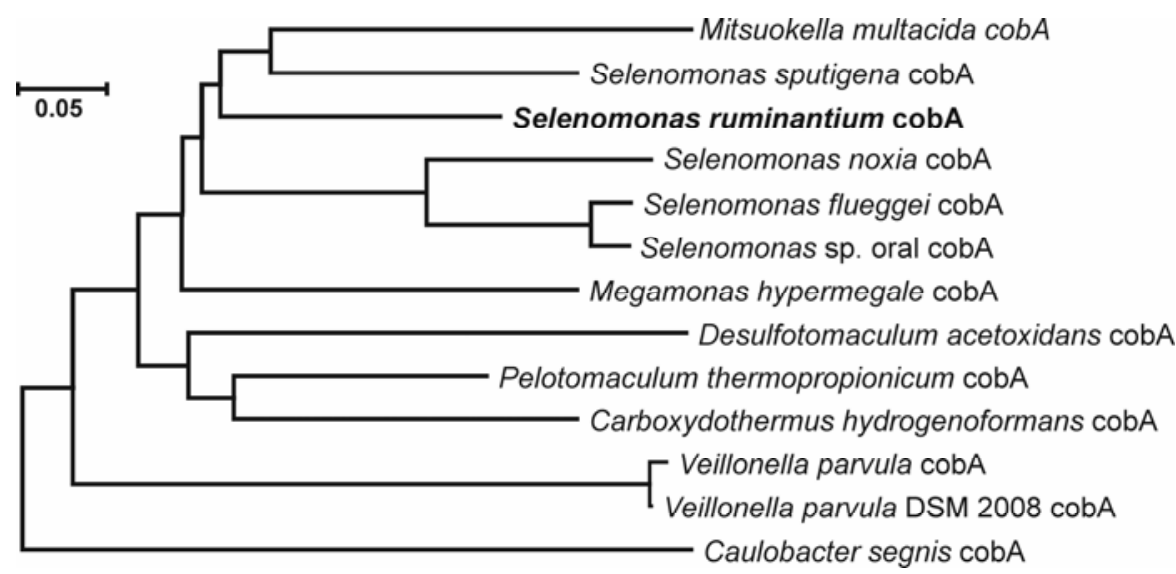

Fig. 2. Phylogenetic tree showing relatedness of $S$. ruminantium CobA sequence (shown in bold). The tree was constructed using neighbour-joining algorithm implemented in MEGA 4 software. The sequence of alphaproteobacterium Caulobacter segnis CobA was used as an outgroup.

Considering the fact that the cobA gene is located between highly conserved sequences found on $S$. ruminantium plasmids, which might carry out a recombinationmediated exchange of the gene or complete gene cassettes; and that protein phylogenetic comparisons also indicate possible horizontal transfer of this gene between different species, it is possible that a certain part encoding $\mathrm{B}_{12}$ pathway enzymes could have been gained in mechanisms of horizontal transfer.

Acknowledgment: This publication is the result of the projects No. 26220120001 and 26220120043 implementation supported by the Research \& Development Operational Programme funded by the ERDF.

\section{References}

ALTSCHUL, S.F., GISH, W., MYERS, E.W., LIPMAN, D.J.: Basic local alignment search tool. J. Mol. Biol., 215, 1990, 403-410. 
ANDERSON, P.J., ENTSCH, B., MCKAY, D.B.: A gene, cobA + hemD, from Selenomonas ruminantium encodes a bifunctional enzyme involved in the synthesis of vitamin B12. Gene, 281, 2001, 63-70.

BATTERSBY, A.R.: How nature builds the pigments of life: the conquest of vitamin $B_{12}$. Science, 264, 1994, 1551-1557.

CALDWELL, D.R., BRYANT, M.P.: Medium without rumen fluid for nonselective enumeration and isolation of rumen bacteria. Appl. Microbiol., 14, 1966, 794-801.

CLARK, B., HOLMS, W.H.: Control of the sequential utilization of glucose and fructose by Escherichia coli. J. Gen. Microbiol., 95, 1976, 191-201.

DUDA, J., PEDZIWILK, Z., ZODROW, K.: Studies on the vitamin B $_{12}$ content of the leguminous plants. Acta Microbiol Pol, 6, 1967, 233-238.

DRYDEN, L.P., HARTMAN, A.M., BRYANT, M.P., ROBINSON, I.M., MOORE, L.A.: Production of vitamin $\mathrm{B}_{12}$ and vitamin $\mathrm{B} 12$ analogues by pure cultures of ruminal bacteria. Nature, 14, 1962, 201-202.

MARTENS, J.-H., BARG, H., WARREN, M.J., JAHN, D.: Microbial production of vitamin $\mathrm{B}_{12}$. Appl. Microbiol. Biotechnol, 58, 2002, 275-285.

NAKAMURA, M., NAGAMINE, T., OGATA, K., TAJIMA, K., AMINOV, R.I., BENNO, Y.: Sequence analysis of small cryptic plasmids isolated from Selenomonas ruminantium S20. Current Microbiol., 38, 1999, 107-112.

POSPIECH, A., NEUMANN, B.: A versatile quick/prep of genomic DNA from grampositive bacteria. Trends Genet., 11, 1995, 217-218.

RICKE, S.C., MARTIN, S.A., NISBET, D.J.: Ecology, metabolism, and genetics of ruminal selenomonads. Crit. Rev. Microbiol., 22, 1996, 27-65.

RODIONOV, D.A., VITRESCHAK, A.G., MIRONOV, A.A., GELFAND, M.S.: Comparative genomics of the vitamin $\mathrm{B}_{12}$ metabolism and regulation in prokaryotes. J Biol. Chem., 278, 2003, 41148-41159.

ROESSNER, C.A., SCOTT, A.I.: Fine-tuning our knowledge of the anaerobic route to cobalamin (vitamin B12). J Bacteriol., 188, 2006, 7331-7334.

TAMURA, K., DUDLEY, J., NEI, M., KUMAR, S.: MEGA4: Molecular Evolutionary Genetics Analysis (MEGA) software version 4.0. Mol. Biol. Evol., 24, 2007, 1596-1599. 